\title{
ANALYSIS OF CORRELATION BETWEEN THE ENERGY DEMAND AND ELECTRICITY RATE AND ENVIRONMENT TEMPERATURE AT THE COMPETITIVE MARKET OF THE URAL GRID COMPANY OF UNIFIED ENERGY SYSTEM
}

V.G. Mokhov ${ }^{1}$, mokhov50@mail.ru, T.S. Demyanenko ${ }^{1}$, oop_flp@mail.ru.

${ }^{1}$ South Ural State University, Chelyabinsk, Russian Federation.

The article covered the electric energy consumer's reaction on tariffs and ambient temperature changes in the Unified Energy System of the Ural in the period of time after restructuring RJSC "UES of Russian Federation". Factual data of Unified Energy System of Russia's System operator shows how indicator values of electric energy consumption elasticity changes with shifting of the youngest competitive markets of electric energy and power in Russia to stationary operating condition: consuming turns from elastic to inelastic according to price. Linear correlation coefficients were calculated for the volume of consumption and the ambient temperature; Rate day-ahead market and temperature; consumption and the market rate on the day-ahead data for 2009 - 2014. Proved an inverse relationship of consumption of electrical energy from the ambient temperature, what confirms the actual transition to a competitive market of electricity production.

Keywords: regression equation; elasticity of energy consumption; rate; the dependence of energy consumption by the ambient temperature; the linear regression.

\section{Introduction}

Electric energy consumption accurate prediction is a problem discussed in many scientific studies [1, 2]. Its relevance is evident. The more accurate to the practical consumption the projected value is, the cheaper electric power is, as its production level is known. Eclectic energy consumption prediction is a complex multiparametric task, which includes the following parameters:

- season;

- the time of day;

- work-week;

- environment temperature;

- daylight hours duration;

- etc.

This paper considers electric energy consumption dependence not only on the abovementioned parameters, but also on electricity rates.

\section{Determination of the Coefficient of Correlation Between the Studied Parameters}

Data in are taken from the official website of the Federal Grid Company of Unified Energy System (http: //www.so-ups.ru/). The selected data for calculations represent 
consumption data and day-ahead electricity market price (DAM) of the Ural unified energy system (UES) from January 1, 2014 till December 31, 2014.

Figures 1 and 2 represent the graphics of electric energy consumption and its rates during 2014.

Figure 1 shows a significant reduction of consumption during summer period while Figure 2, on the contrary, represents a slight increase in the electric energy consumption services cost within the same period. It is concluded that a reduction in consumption causes an increase in the cost of the electricity [2].

The main indicator of dependence is the correlation coefficient. Correlation is a statistic relationship of two or more independent variables (variables are numbers, or quantities that increases or decreases over time, or takes different values in different situations) [3]. The change in the value of one of them causes a change in other values. As a mathematical measure of correlation of the two variables is the correlation coefficient [4].

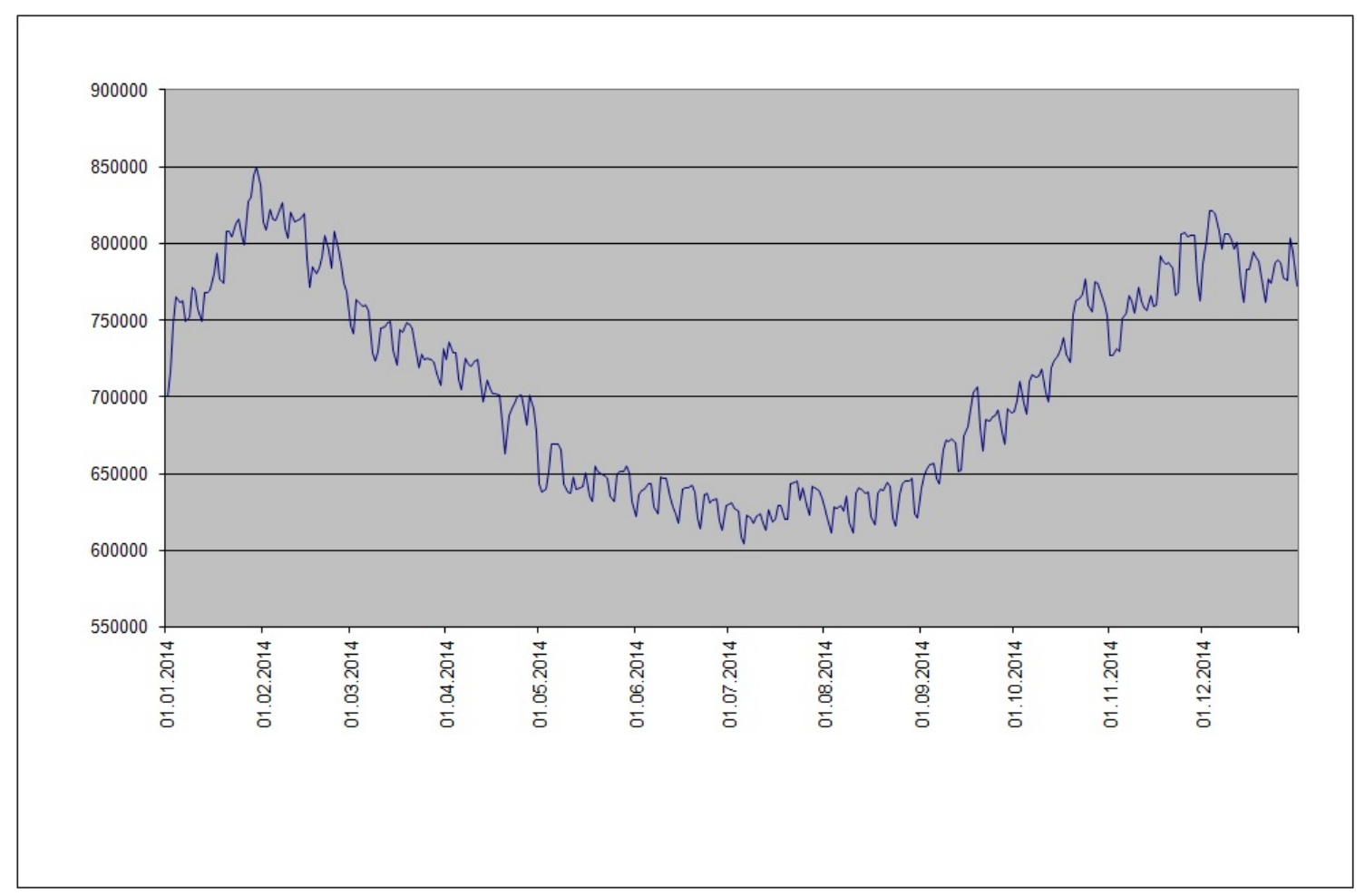

Fig. 1. Ural Grid Company electric energy consumption from 01.01.2014 till 31.12.2014

Correlation coefficients may be direct (positive) and inverse (negative). If any parameter value increases and the other undertakes the loss, the correlation coefficient is inverse. If any parameter value increases and the other undertakes an increase as well, the correlation coefficient is direct. Another possible situation is absence of a statistical correlation. An example can be independent random variables [4].

The correlation coefficient $r_{y x}$ perfectly performs the tendency when one variable increases under increase of another. Its value are always within $[-1 ; 1]$ range. The closer the variable value gets to -1 or 1 , the more the correlation between the observed variables gets. If $r_{y x}=0$ there is no correlation the complete absence of correlation between the observed variables. If $r_{y x}=-1$ or $r_{y x}=1$ there is a functional dependence of variables. 


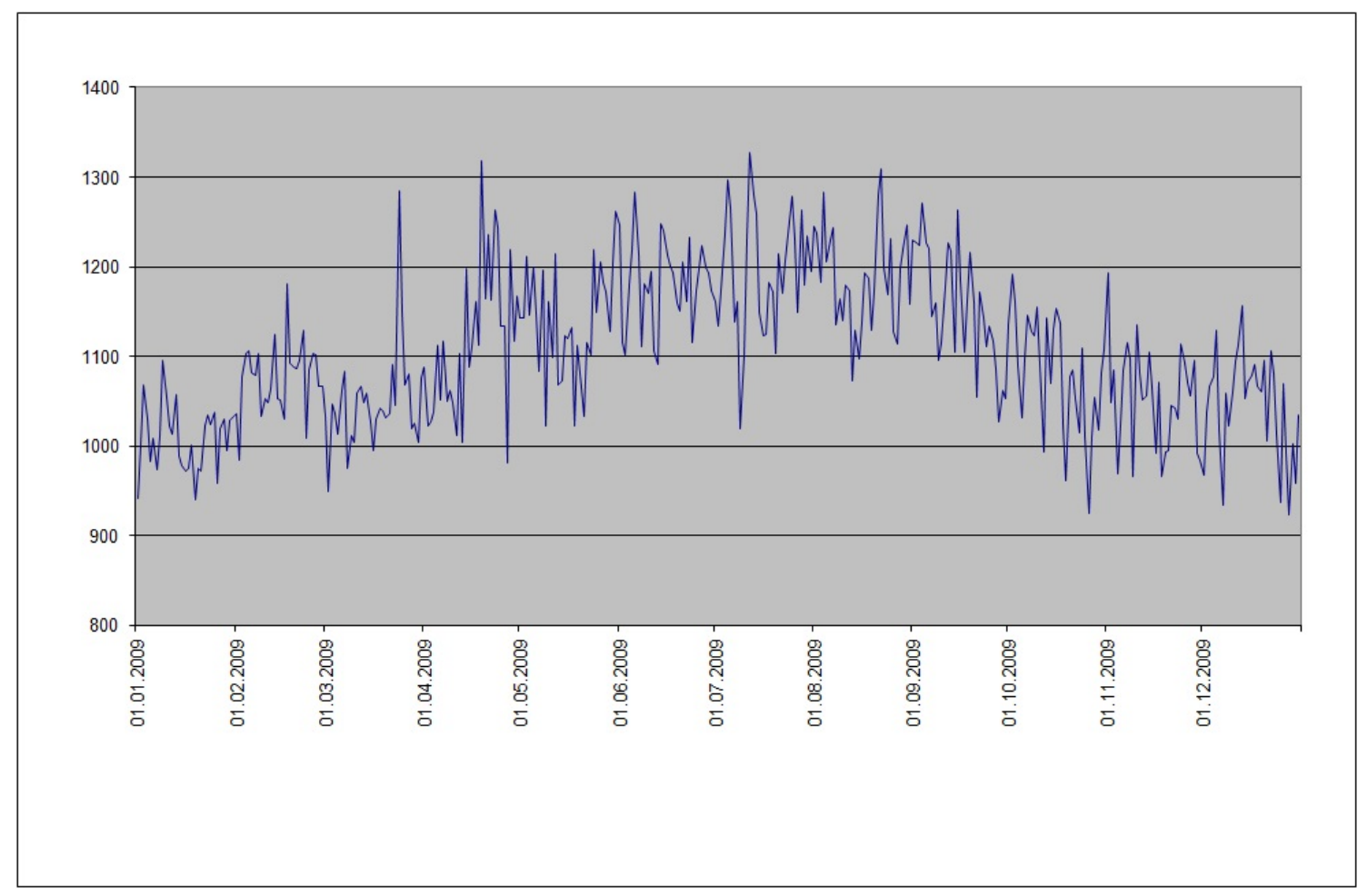

Fig. 2. DAM of the electric energy service rate from 01.01.2014 till 31.12.2014

The correlation coefficient between the two variables $\mathrm{X}$ and $\mathrm{Y}$ is calculated with the formula:

$$
r_{y x}=\frac{n \cdot \sum x_{i} y_{i}-\left(\sum x_{i}\right) \cdot\left(\sum y_{i}\right)}{\sqrt{\left(n \cdot \sum x_{i}^{2}-\left(\sum x_{i}\right)^{2}\right) \cdot\left(n \cdot \sum y_{i}^{2}-\left(\sum y_{i}\right)^{2}\right)}} .
$$

The correlation coefficient between the electric energy consumption and the DAM rate of Ural UES is $-0,66717$, indicating a slight increase in prices under significant reduction in consumption.

As a season is impossible to estimate quantitavely (only separate parameters may be estimated quantitavely), it is obvious the use of expert evaluations, which construct graphics of electric energy consumption and day-ahead market costs within 2009-2014 (Figure 3).

The Figure 3 clearly observes consumption decrease during summer period due to daylight hours extending and the environment temperature increase. Correlation coefficient approximates each year to -1 index is an evidence of dependence between the electric energy consumption and the environment temperature. So when temperature rises the consumption decreases. The calculated values of correlation coefficients for the period 2009-2014. are given in Table.

\section{Determination of the Coefficient of Elasticity of Demand for Electricity by the Rate}

The problem of determining a correlation ratio is to calculate how a correlative relationship gets close by its force to the functional ratio with a help of special indexes. 


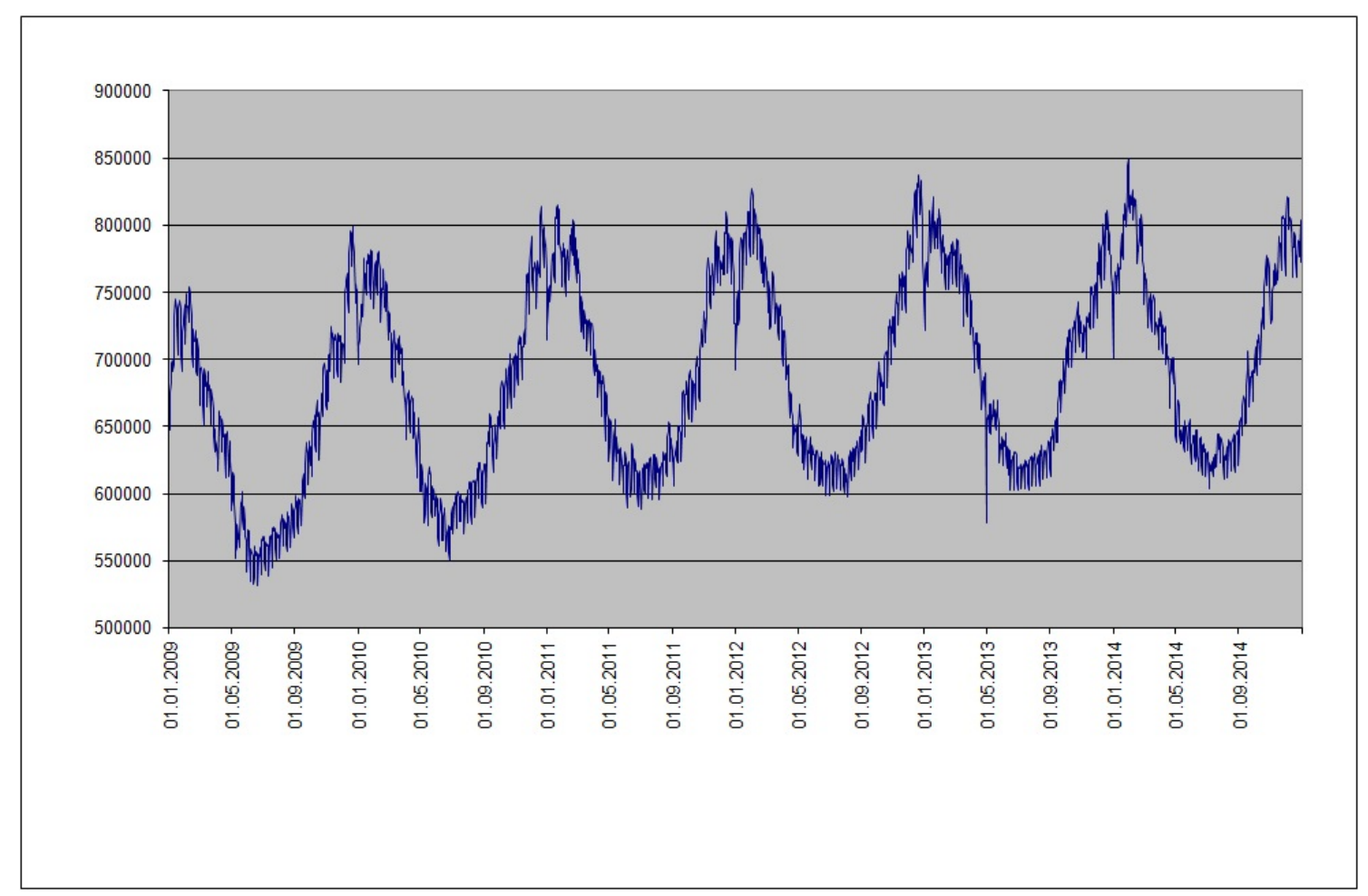

Fig. 3. Electric energy consumption of Ural UES during 2009-2014

One of them is an elasticity coefficient. It represents a ratio force of X parameter with $\mathrm{Y}$ result. It also represents a percent change of $\mathrm{Y}$ under change of $\mathrm{X}$ by $1 \%$.

The elasticity of demand $(\mathrm{W})$ under the rate of $(\mathrm{P})$ is the valued:

$$
E_{w}=\frac{\partial W / W}{\partial P / P} .
$$

It is advisable to determine an elasticity coefficient for each year based on a liner type regression. Calculated values of elasticity coefficients are given in Table.

Table

Correlation coefficients according to Ural UES during 2009 - 2014

\begin{tabular}{|l|l|l|l|l|}
\hline \multirow{2}{*}{ Year } & \multicolumn{3}{|c|}{ Correlation coefficient } & $\begin{array}{l}\text { Elasticity } \\
\text { coefficient }\end{array}$ \\
\hline & $\begin{array}{l}\text { Consumption } \\
\text { Temperature }\end{array}$ & $\begin{array}{l}\text { DAM costs / } \\
\text { Temperature }\end{array}$ & $\begin{array}{l}\text { Consumption } \\
\text { DAM costs }\end{array}$ & $\begin{array}{l}\text { Consumption } \\
\text { DAM costs }\end{array}$ \\
\hline 2009 & $-0,93053789$ & 0,15544 & $-0,0298$ & $-0,0197$ \\
\hline 2010 & $-0,92759003$ & 0,16844 & $-0,0837$ & $-0,07258$ \\
\hline 2011 & $-0,94353654$ & 0,11784 & $-0,1554$ & $-0,17754$ \\
\hline 2012 & $-0,95561438$ & 0,46453 & $-0,8074$ & $-0,32678$ \\
\hline 2013 & $-0,95154951$ & 0,50602 & $-0,4553$ & $-0,43097$ \\
\hline 2014 & $-0,94116429$ & 0,66966 & $-0,6672$ & $-0,82046$ \\
\hline
\end{tabular}




\section{Conclusions}

1. There is an inverse correlation between the consumption and environment temperature, where the correlation coefficient gets to -1 within the whole period observed. Therefore, temperature is an important parameter for the predictions of electric energy consumption.

2. The consumption dependence on DAM cost increases greatly by 2012 and slightly decreases in 2013 and 2014.

3. Speaking about the 2009 - 2011 period there observed a complete inelastic demand at price that is associated with the beginning of the electric energy price formation. From 2012 till 2014 the elasticity coefficient (in absolute value) is gradually increasing. However, during 2012 - 2013 its value is still much less than 1, which is a clear sign of inelasticity. In 2014 the coefficient takes the level which indicates rate elasticity as under the rate increase by $10 \%$, the consumption demand drops by more than $8 \%$.

4. The correlation coefficient between the DAM cost and environment temperature is increasing steadily by 2014. The reform by "UES of Russia" RJSC, held in 2008, is directly related to this fact. It carried out the transition to the competitive market of electric energy production. The elasticity of rate demand has an inverse correlation and a steady growth. That means the lower the price is, the greater demand becomes. The results of the transition to a competitive market are observed only in 2014. As mentioned above, the consumption depends heavily on the environment temperature. The elasticity of rate demand appears only by 2014 . The factors are responsible for a significant correlation increase between the DAM cost and environment temperature which took place by 2014 .

\section{References}

1. Tikhonov E.E. Prognozirovanie $v$ usloviyakh rynka [Predictions under Market Conditions]. Nevinnomyssk, 2006. (in Russian)

2. Mokhov V.G, Demyanenko T.S. [Predictions for Electric Energy Consumption and Power at the Wholesale Market]. Bulletin of the South Ural State University. Series: Economics and Management, 2014, vol. 8, no. 2, pp. 86-92. (in Russian)

3. Pradhan R.P. Forecasting Exchange Rate in India: An Application of Artificial Neural Network Model. Journal of Mathematics Research, 2010, vol. 1372, no. 4, issue 1, pp. 111-117.

4. Drucker P.F. Management Challenges for the 21st Century. New York, HarperBusiness, 1999.

Veniamin G. Mokhov, doctor of economics, professor, department of Business and Management, South Ural State University, Chelyabinsk, Russian Federation, mokhov50@mail.ru.

Tatyana S. Demyanenko, senior lectured, department of Mathematical Modelling, South Ural State University, Chelyabinsk, Russian Federation, oop_flp@mail.ru.

Received November 17, 2015 


\title{
ИССЛЕДОВАНИЕ ЗАВИСИМОСТИ СПРОСА И ТАРИФА НА ЭЛЕКТРОЭНЕРГИЮ ОТ ТЕМПЕРАТУРЫ ОКРУЖАЮЩЕЙ СРЕДЫ НА КОНКУРЕНТНОМ РЫНКЕ ОБЪЕДИНЕННОЙ ЭНЕРГОСИСТЕМЫ УРАЛА
}

\author{
В.Г. Мохов, Т.С. Демъяненко
}

В статье исследована реакция потребителей электрической энергии на изменение тарифов и температуры окружающей среды в Объединенной энергосистеме Урала, в период после реформирования ОАО "РАО ЕЭС России". На фактических данных Системного оператора Единой энергетической системы России показано, как меняются значения показателей эластичности спроса на электроэнергию по мере перехода самого молодого в мире конкурентного рынка электрической энергии и мощности России в стационарный режим работы: потребление из неэластичного приближается к эластичному по цене. Линейные коэффициенты корреляции были рассчитаны для объема потребления и температуры окружающей среды; тарифа рынка на сутки вперед и температуры; объема потребления и тарифа рынка на сутки вперед для 2009 - 2014 гг. Доказана обратная зависимость между потреблением электрической энергии и температурой окружающей среды, что подтверждает фактический переход к конкурентному рынку производства электроэнергии.

Ключевые слова: уравнение регрессии; эластичность потребления электроэнергии; тариф; зависимость потребления электроэнергии от температуры окружающей среды; линейная регрессия.

\section{Литература}

1. Тихонов, Э.Е. Прогнозирование в условиях рынка / Э.Е. Тихонов. - Невинномысск, 2006.

2. Мохов, В.Г. Прогнозирование потребления электрической энергии на оптовом рынке энергии и мощности / В.Г. Мохов, Т.С. Демьяненко // Вестник ЮУрГУ. Серия: Экономика и менеджмент. - 2014. - Т. 8, № 2. - С. 86-92.

3. Pradhan, R.P. Forecasting Exchange Rate in India: An Application of Artificial Neural Network Model / R.P. Pradhan // Journal of Mathematics Research. - 2010. - V. 1372, № 4, issue 1. - P. 111-117.

4. Drucker, P.F. Management Challenges for the 21st Century / P.F. Drucker. - New York, HarperBusiness, 1999.

Мохов Вениамин Геннадъевич, доктор экономических наук, профессор, кафедра предпринимательства и менеджмента, Южно-Уральский государственный университет (2. Челябинск, Российская Федерация), mokhоv50@таil.ru.

Демъяненко Татьяна Сергеевна, стариий преподаватель, кафедра математического моделирования, Южно-Уральский государственный университет (г. Челябинск, Российская Федерачия), оор_flp@таil.ru.

Поступила в редакиию 17 ноября 2015. 